\title{
Investigation of Grid Connected PV System with Electrial Appliances, Electric Vehicles and Battery Systems using PVsol Software
}

\author{
M.Pushpavalli ${ }^{*}$, P.Abirami ${ }^{2}$,P.Sivagami ${ }^{3}$, V.Geetha ${ }^{4}$ \\ (pushpavalli.eee@,sathyabama.ac.in ${ }^{l}$,abiramiramkumar80@gmail.com²,sivagamitec@,gmail.com³.gee \\ thasendray28@gmail.com ${ }^{4}$ )
}

Assistant Professor/EEE Sathyabama Institute of Science \& Technology $1,2,3,4$

\begin{abstract}
Three different Modules areas considered for PV panels which is connected to grid, Electric appliances, Electric Vehicles and battery system in turn analyzed using PV sol simulation. The Main Objective of this paper is before implementing the PV panel in real time, examine the overview set-up of the system i.e. Module areas of the PV panel with different tracking methods along with Climate data for the particular location. This is Further investigated with number of PV modules needed for the required output. The overall system identified with the total number of inverters and battery systems. This system also analyzes the energy forecasting over a period of year and utilized for battery charging, Electric Vehicle Charging, Grid feeding and consumption for appliances. The system not only focus the technical aspects but also the emission of $\mathrm{CO} 2$ avoided, Financial analysis like investment costs and return on assets.
\end{abstract}

Keywords: PV panels, Grid, Electric Vehicles, $\mathrm{CO} 2$ emission and financial analysis.

\section{Introduction}

$\mathrm{PV}$ is the most prominent renewable energy for utilisation. The researcher mainly focusses the PV for energy utilisation. The main challenge of erecting the PV source in real time is cost and availability of the source [1]. The research always focus on the renewable energy is suitable converters, inventors and controllers. But in real time financial analysis, maintenance cost and return on assets are focused as an important parameter [2]. Using conventional energy rather than renewable energy reduces the emission of carbon di oxide [3]. PV source utilised for grid connection, charging the battery, supplying the electrical appliances and charging electrical vehicles [4]. Maximum Power Point Tracking (MPPT) always ensures the tracking of maximum power by using controller or axis rotation of PV panel [5-9]. PV sol software ensures the connection of PV to stand-alone, ON grid connected, OFF grid connected. Similarly, PV can connect with various installation type like mounted in roof, roof parallel and open space [6]. Different coupling methods like AC coupling and DC coupling are available to integrate the renewable system with load [7]. While pumping the renewable energy to grid, number of phases, grid voltage, frequency and power factors are considered [8]. Multi input Converters plays important role of connecting more than one source [9-10]. 


\section{Block Diagram of Proposed System}

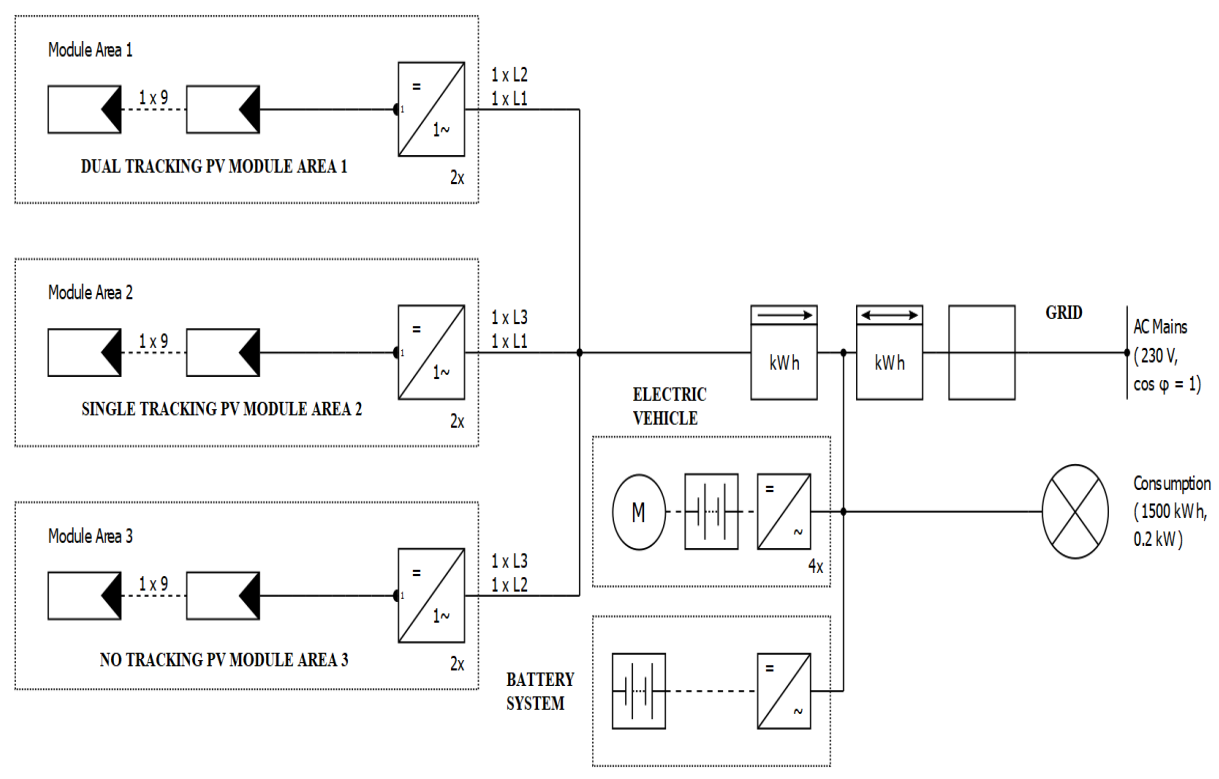

Fig. 1. Proposed block diagram of PV system connected to Grid,Battery and Electric Vehicle

Figure 1 Proposed the block diagram of PV system with three different tracking methods like Dual axis tracking,single axis tracking and without any axis tracking. This system also stores the energy in the battery,supplies the power to electric vehicle,electric appliances and further surpulus power feeds to Grid .

Figure 2 represents the specifications of PV modules areas.PV module area1 implemented using the dual axis tracking. The maximum inclination angle is $90 \mathrm{o}$ and azimuth angle of opening is $200 \mathrm{o}$. PV module area 2 implemented using the single axis tracking. The maximum inclination angle is 380 and azimuth angle of opening is $200 \mathrm{o}$. PV module area3 implemented with no axis tracking. The maximum inclination angle is $30 \mathrm{o}$ and azimuth angle of opening is $180 \mathrm{o}$.All the PV module panels installed in Mounted-Roof type and 200WpSilicon monocrystalline type PV Panel only used.Total number of PV modules used in each area is 18. Figure 3 represents the temperature per Module area. By comparing this Module area 1 capture more temperature than other two module areas.Because of dual tracking method in module areal captures more temperature.Figure 4 represents the irradiance per Module area. By comparing this Module area 1 capture more irradiance than other two module areas.Because of dual tracking method in module areal captures more irradiance.

Figure 5 represents PV Energy for 25 Years. The PV analysis taken at location of Minambakkam,Chennai,India.The Latitude of location is 130 ,Longitude is $80 \mathrm{o} 101580$ .Annual sum of global radiation is $1926 \mathrm{KWh} / \mathrm{m} 2$.Annual Average Temperature is 28.2oC.The observation period is taken for nearly 10 years and resolution for hourly basis.Figure 6 represents the Energy balance based on the irradiance level 


\begin{tabular}{|c|c|c|}
\hline \multicolumn{3}{|l|}{ Module Area 1} \\
\hline PV Generator Output & 3.6 & $k W p$ \\
\hline PV Generator Surface & 29.2 & $\mathrm{~m}^{2}$ \\
\hline Global Radiation at the Module & 2452.4 & $\mathrm{kWh} / \mathrm{m}^{2}$ \\
\hline PV Generator Energy (AC grid) & 7010.5 & $\mathrm{kWh} /$ Year \\
\hline Spec. Annual Yield & 1947.4 & $\mathrm{kWh} / \mathrm{kWp}$ \\
\hline Performance Ratio (PR) & 79.5 & $\%$ \\
\hline \multicolumn{3}{|l|}{ Module Area 2} \\
\hline PV Generator Output & 3.6 & kWp \\
\hline PV Generator Surface & 30.2 & $\mathrm{~m}^{2}$ \\
\hline Global Radiation at the Module & 2339.9 & $\mathrm{kWh} / \mathrm{m}^{2}$ \\
\hline PV Generator Energy (AC grid) & 6703.8 & kWh/Year \\
\hline Spec. Annual Yield & 1862.2 & $\mathrm{kWh} / \mathrm{kWp}$ \\
\hline Performance Ratio (PR) & 79.6 & $\%$ \\
\hline \multicolumn{3}{|l|}{ Module Area 3} \\
\hline PV Generator Output & 3.6 & $k W p$ \\
\hline PV Generator Surface & 30.2 & $\mathrm{~m}^{2}$ \\
\hline Global Radiation at the Module & 1851.4 & $\mathrm{kWh} / \mathrm{m}^{2}$ \\
\hline PV Generator Energy (AC grid) & 5188.6 & kWh/Year \\
\hline Spec. Annual Yield & 1441.3 & $\mathrm{kWh} / \mathrm{kWp}$ \\
\hline Performance Ratio (PR) & 77.8 & $\%$ \\
\hline
\end{tabular}

Fig. 2.Three different tracking PV module areas with different tracking methods
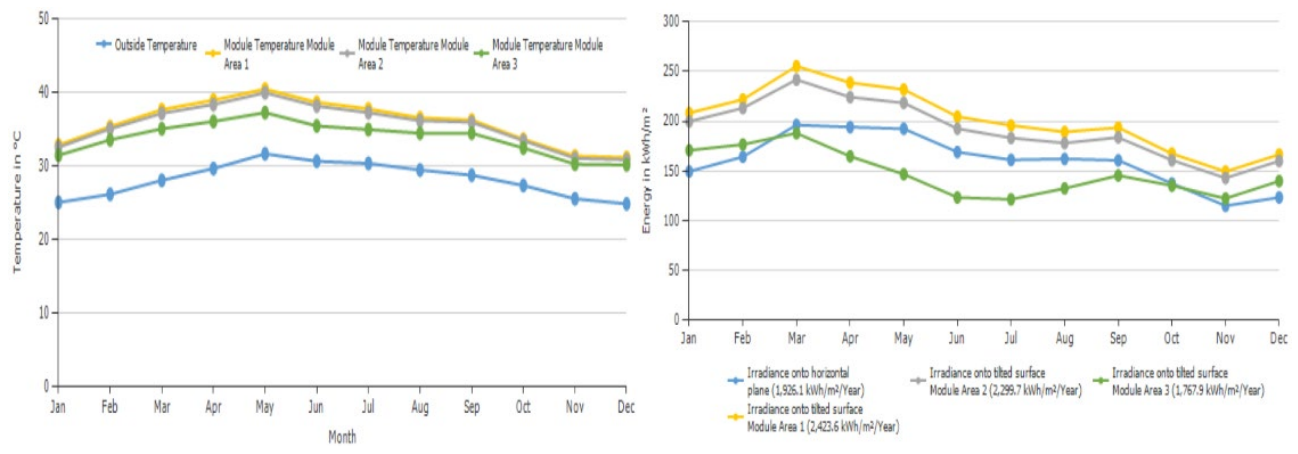

Fig. 3. Temperature per Module areaFig. 4. Irradiance per Module area

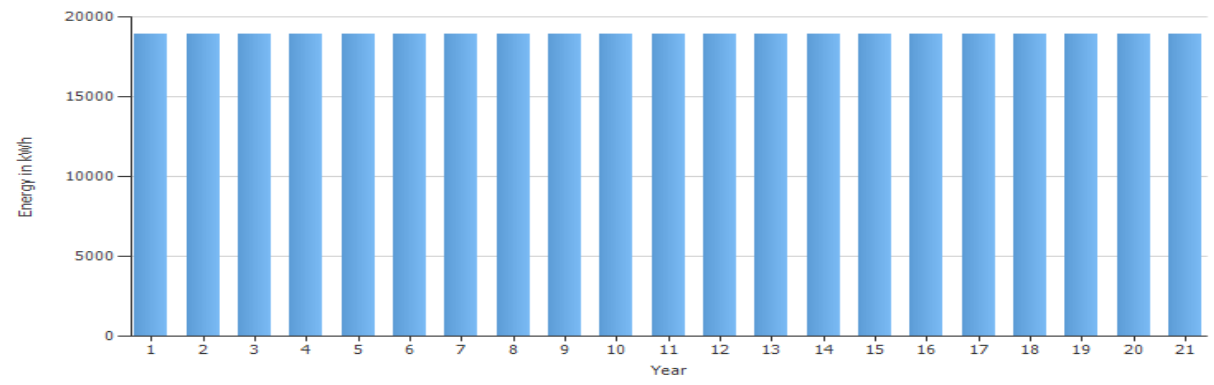

Fig. 5. PV Energy during Observation Period 


\begin{tabular}{|c|c|c|c|}
\hline Module Area 1 & & & \\
\hline Global radiation - horizontal & $1,926.13$ & $\mathbf{k W h} / \mathbf{m}^{2}$ & \\
\hline Deviation from standard spectrum & -19.26 & $\mathrm{kWh} / \mathrm{m}=$ & $-1.00 \%$ \\
\hline Ground Reflection (Albedo) & 45.26 & $\mathrm{~kW} / \mathrm{h} / \mathrm{m}^{2}$ & $2.37 \%$ \\
\hline Orientation and inclination of the module surface & 500.28 & $\mathrm{kWh} / \mathrm{m}^{2}$ & $25.63 \%$ \\
\hline Shading & 0.00 & $\mathrm{~kW} / \mathrm{h} / \mathrm{m}^{2}$ & $0.00 \%$ \\
\hline Reflection on the Module Interface & -28.77 & $\mathrm{kWh} / \mathrm{m}^{2}$ & $-1.17 \%$ \\
\hline Global Radiation at the Module & $2,423.63$ & $\mathbf{k W h} / \mathbf{m}^{2}$ & \\
\hline Module Area 2 & & & \\
\hline Global radiation - horizontal & $1,926.13$ & $\mathbf{k W h} / \mathbf{m}^{2}$ & \\
\hline Deviation from standard spectrum & -19.26 & $\mathrm{kWh} / \mathrm{m}^{2}$ & $-1.00 \%$ \\
\hline Ground Reflection (Albedo) & 40.42 & $\mathrm{kWh} / \mathrm{m}^{2}$ & $2.12 \%$ \\
\hline Orientation and inclination of the module surface & 392.61 & $\mathrm{kWh} / \mathrm{m}^{2}$ & $20.16 \%$ \\
\hline Shading & 0.00 & $\mathrm{~kW} / \mathrm{h} / \mathrm{m}^{2}$ & $0.00 \%$ \\
\hline Reflection on the Module Interface & -40.16 & $\mathrm{kWh} / \mathrm{m}^{2}$ & $-1.72 \%$ \\
\hline Global Radiation at the Module & $2,299.74$ & $\mathbf{k W h} / \mathbf{m}^{2}$ & \\
\hline Module Area 3 & & & \\
\hline Global radiation - horizontal & $1,926.13$ & $\mathbf{k W h} / \mathrm{m}^{2}$ & \\
\hline Deviation from standard spectrum & -19.26 & $\mathrm{kWh} / \mathrm{m}^{2}$ & $-1.00 \%$ \\
\hline Ground Reflection (Albedo) & 25.55 & $\mathrm{kWh} / \mathrm{m}^{2}$ & $1.34 \%$ \\
\hline Orientation and inclination of the module surface & -81.05 & $\mathrm{kWh} / \mathrm{m}^{2}$ & $-4.19 \%$ \\
\hline Shading & 0.00 & $\mathrm{kWh} / \mathrm{m}^{2}$ & $0.00 \%$ \\
\hline Reflection on the Module Interface & -83.44 & $\mathrm{kWh} / \mathrm{m}^{2}$ & $-4.51 \%$ \\
\hline Global Radiation at the Module & $1,767.93$ & $\mathbf{k W W h} / \mathbf{m}^{2}$ & \\
\hline
\end{tabular}

Fig. 6. PV System energy balance for Irradiance

\section{ENERGY FORECASTING}

Figure 7 represents the uses of PV energy for grid feeding,battery charging,Electric vehicle charging and own usage.By seeing above graph March month generation of PV is high. In March month PV generation=1985 KWh, Electric Vehicle charging=702 KWh,Grid feeding=1137 KWh,Battery Charging=76 KWh and remaining power used for own use.In November month generation of PV is low. In November month PV generation=1235 KWh,Electric vehicle charging=583 KWh, Grid feeding $=521 \mathrm{KWh}$,Battery Charging $=67 \mathrm{KWh}$ and remaining power used for own use.

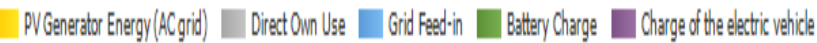

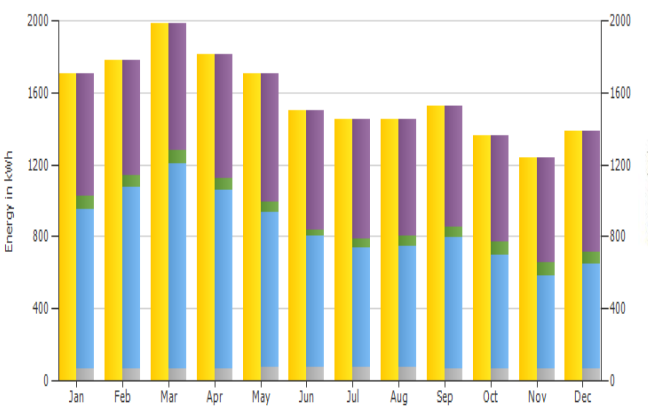

Fig. 7. Uses of PV Energy sources

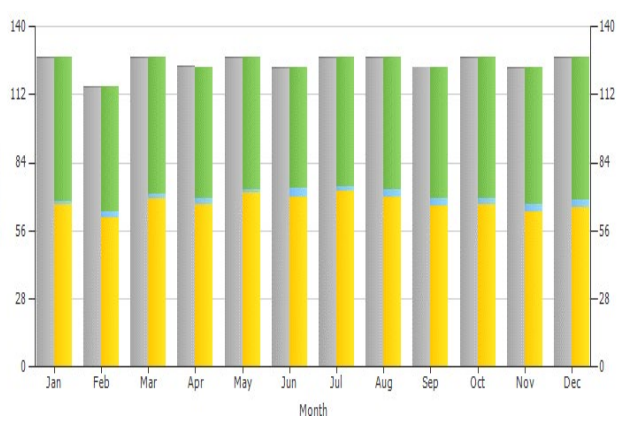

Fig. 8.Electrical Appliances Consumption by different 


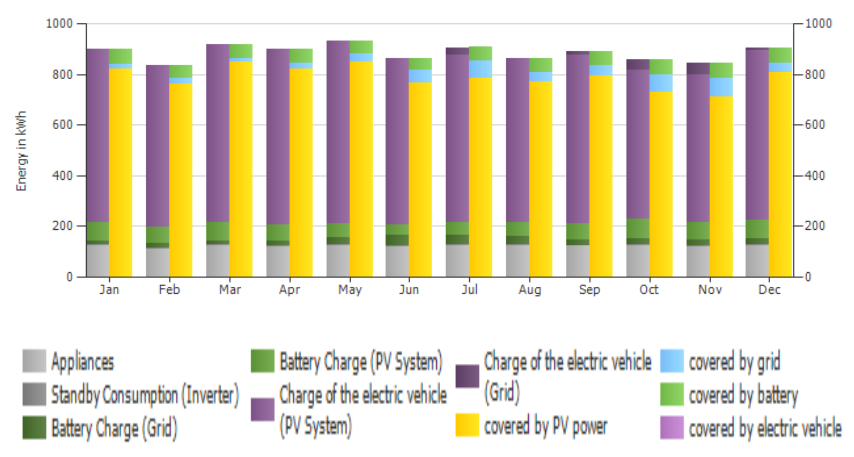

Fig. 9.Total Power Consumption Coverage

Figure 8 represents Electrical Appliances Consumption by different sources like PV,grid and battery.The total Power needed for electric appliance per month is $127.5 \mathrm{KWh}$.In January Month PV power supplies $66.6 \mathrm{KWh}$,battery supplies $59.4 \mathrm{KWh}$ and grid supplies 1.6 KWh.So,Electric appliances get $60 \%$ power from PV ,49\% from battery and 1\% from grid.Figure 9 represents total power consumption and utilization.May Month taken for analysis,In that PV generation $=848 \mathrm{KWh}$,Grid Power $=31.2 \mathrm{KWh}$,Battery Power $=54.6 \mathrm{KWh}$.This Power utilized for charging the Electric Vehicle=720.8 KWh,Electric Appliances utilization $=127.5 \mathrm{KWh}$, Battery charging $=85.7 \mathrm{KWh}$. The most of the power generated from PV and most of the power utilized for electric vehicle charging.

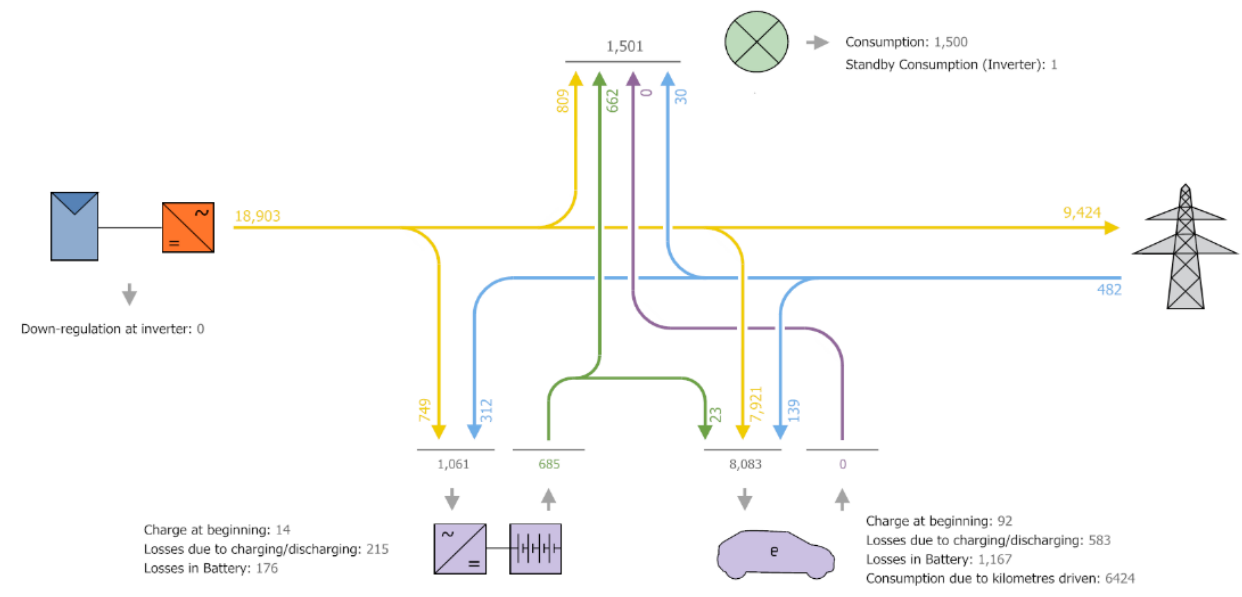

Fig. 10.Energy flow graph

Figure 10 represents energy flow graph for a year .The total power generated from $\mathrm{PV}=18903$ KWh.In that $749 \mathrm{KWh}$ for battery charging,7921 KWh for Electric Vehicle Charging, 9424 for grid feeding and $809 \mathrm{KWh}$ for appliances.Similarly grid also supplies $139 \mathrm{KWh}$ for Electric Vehicle Charging, $312 \mathrm{KWh}$ for battery charging and $30 \mathrm{KWh}$ for appliances. Battery gets 749 
KWh energy through PV and $312 \mathrm{KWh}$ from grid.Total energy for battery charging is 1061 $\mathrm{KWh}$ in that battery supplies $23 \mathrm{KWh}$ for Electric Vehicle Charging and $662 \mathrm{KWh}$ to appliances.

\section{Components of PV System}

\subsection{Inverter}

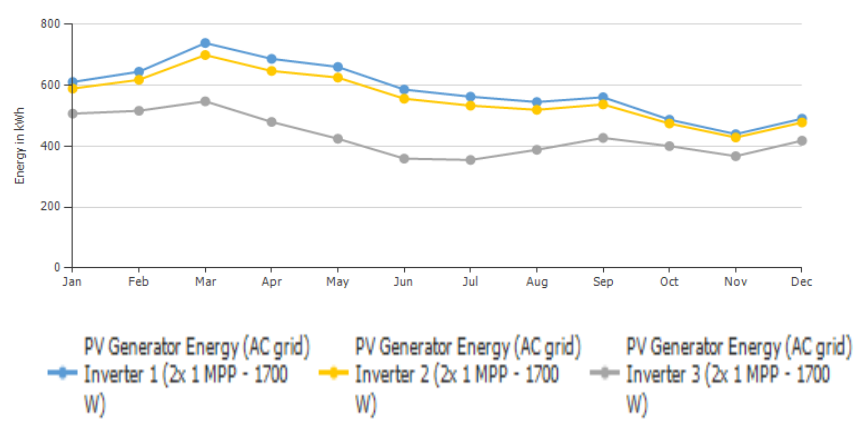

Fig. 11.Production Forecast per Inverte1

Figure 11 represents the production forecast per Inverter.Here three different PV module area has chosen for each module area 2 Inverters needed.Totally 6 inverters are there with a capacity of 1700 Watts each with sizing factor of $105.9 \%$.

Figure 12 represents the Performance ratio of Inverters over a year.The MPPT voltage is around $240 \mathrm{~V}$ fed to the inverter. The Performance ratio of PV module area 1 has high value. Figure 13 represents the energy at the inverter input.This analysis taken for three PV module areas separately. Because of dual tracking method in module areal produces more PV generation energy in AC grid nearly $7010.52 \mathrm{KWh} . \mathrm{PV}$ module area 2 has single axis tracking produces PV generation energy in AC grid nearly $6703.76 \mathrm{KWh}$. PV module area 3 has no axis tracking produces PV generation energy in AC grid nearly 5188.56 KWh.

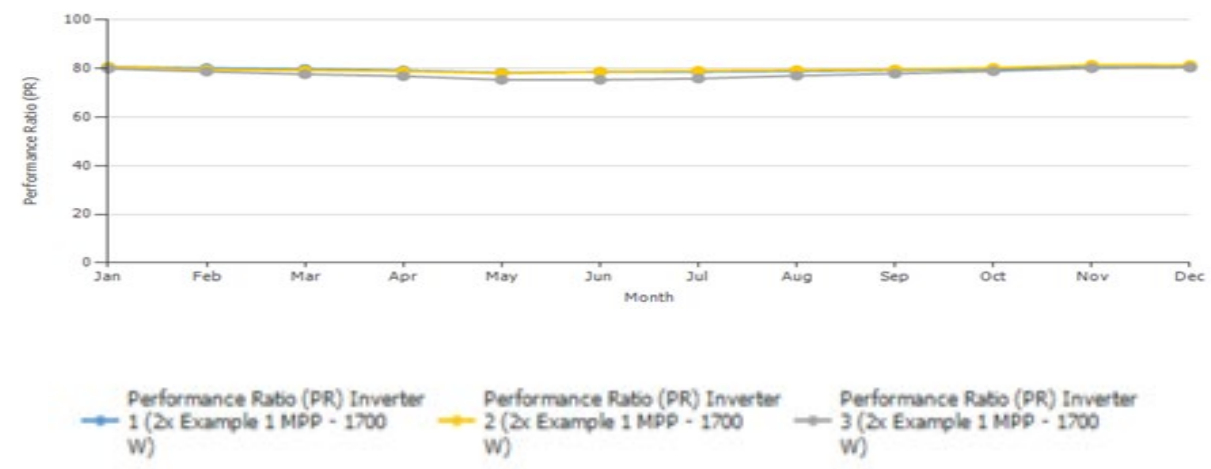


Fig. 12.Performance Ratio of Inverters over a year

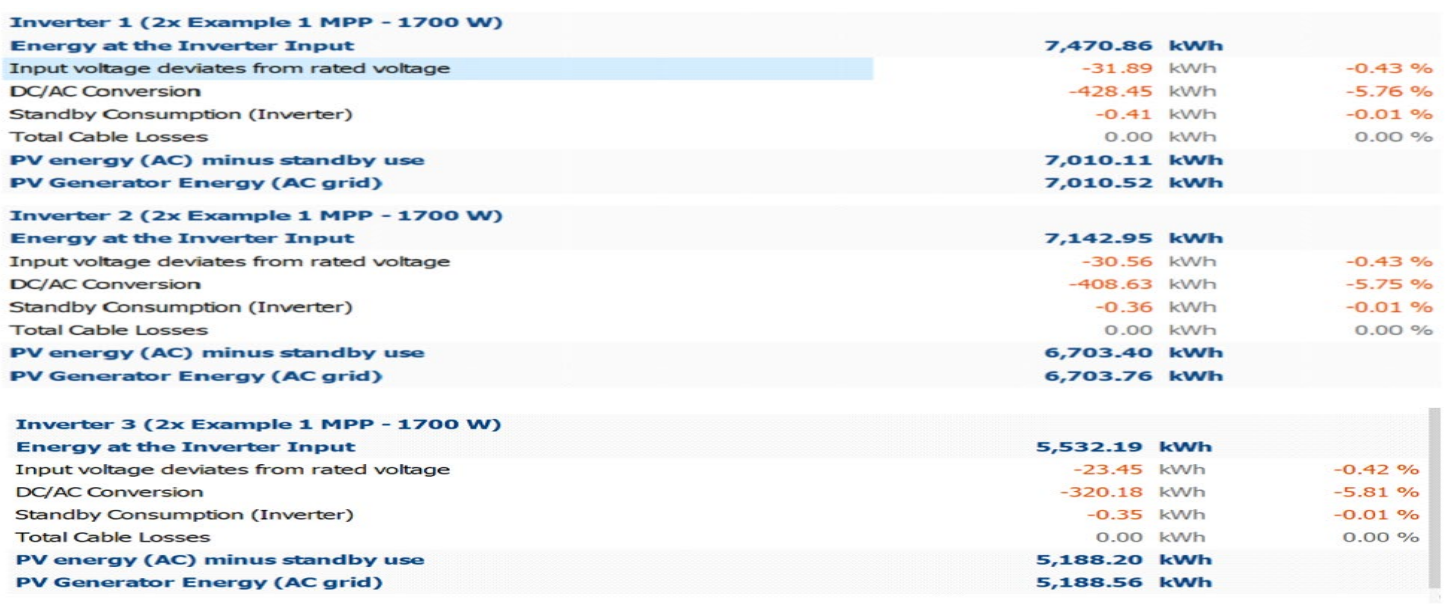

Fig. 13.Performance Ratio of Inverters over a year

\subsection{Battery}

$2 \mathrm{KW}$ nominal output, AC Coupling and 14.45 KWh energy single battery unit is needed for this system. Lead acid type battery is used with a capacity of 2V,1050 Ah.Figure 14 represents Battery Charging for PV system, Grid and Consumption over a month. Battery Mainly used for charging from PV system.Figure 15 and 16 represents the SOC of battery system and Electric vehicle. 60 watts of power wasted due to charging and discharging of the battery.

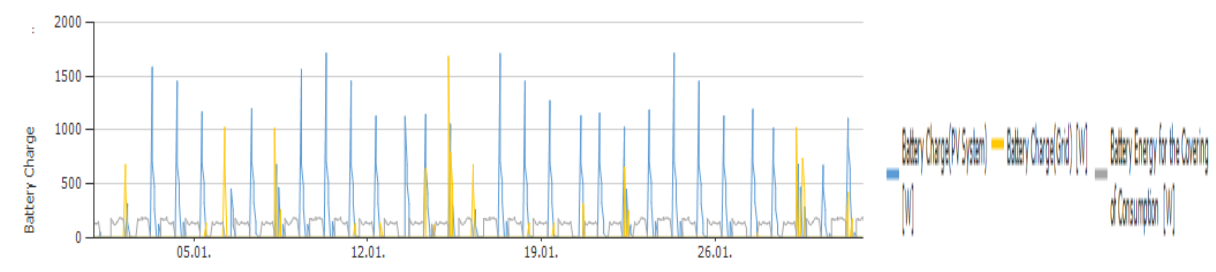

Fig. 14.Battery Charging for PV system, Grid and Consumption over a month
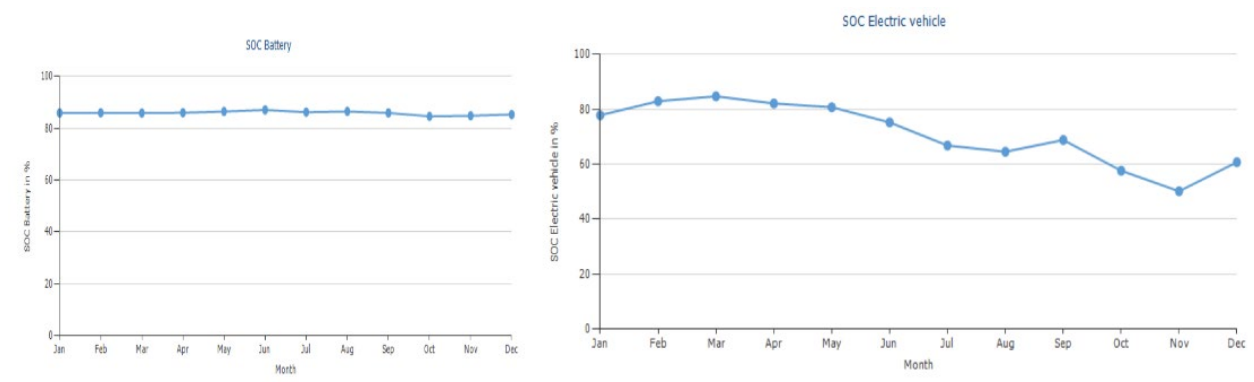
Figure 15 and 16 represents the SOC of battery system and Electric vehicle. 60 watts of power wasted due to charging and discharging of the battery.

\section{Power Utilization}

\subsection{Electric Vehicle}

TABLE 1.ELECTRIC VEHICLE SPECIFICATION

\begin{tabular}{|l|c|}
\hline Charging Power & $3.2 \mathrm{KW}$ \\
\hline Number of Vehicle can Charged & 4 \\
\hline Manufacturer & Ford \\
\hline Battery capacity & $23 \mathrm{KWh}$ \\
\hline Desired Range Per week & $200 \mathrm{KM}$ \\
\hline
\end{tabular}

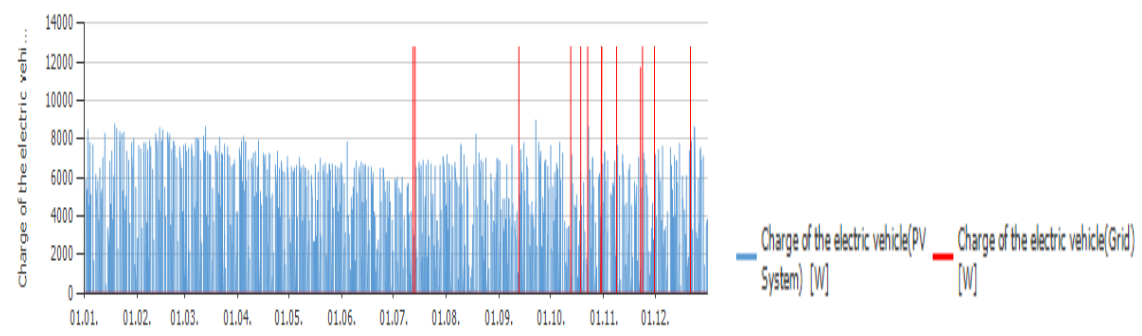

Fig. 17.Charging of the Electric Vehicle over a year

Figure 17 represents Electric Vehicle Charging from PVsystem and Grid .Most of the Power charged from PV only. Due to the shortage of PV power only the grid supplies the power for Electric Vehicle Charging.

\subsection{Electric Appliances}

PV source considered for energizing the Electric appliances also. Research institute with a capacity of $1000 \mathrm{KWh}$ and office building with $16000 \mathrm{~m}^{2}$ a capacity of $500 \mathrm{KWh}$. Totally $1500 \mathrm{KWh}$ for annual consumption with a peak load of $0.2 \mathrm{KW}$. 


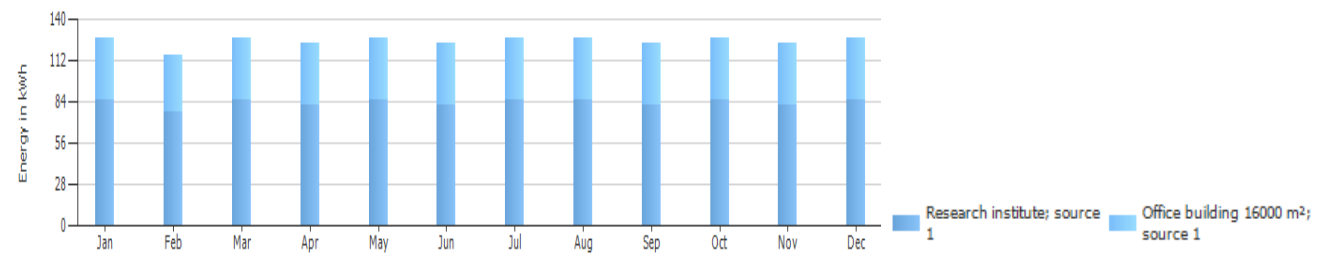

Fig. 18.Load Profile of Electric Appliances

Figure 18 represents load profile of Electric appliances over a year for research institute and office building.

\subsection{Grid}

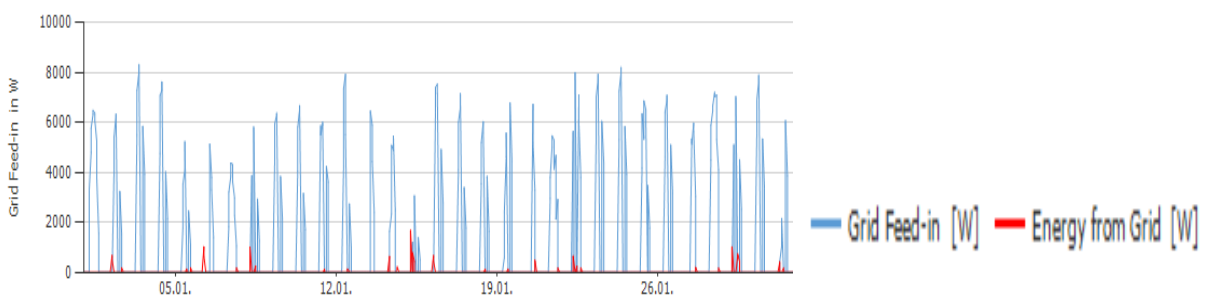

Fig. 19. Energy from grid and Feed in Power to Grid

Figure 19 represents Energy from grid and Power fed to grid for a period of month. Most of the Power fed to grid and less power only extracted from grid for battery charging, electric Vehicle charging and consumption for electric appliances. The Grid specification is three phase,230 Volt Phase Voltage and Power factor is 1.

\section{Financial Analysis}

The total PV generator energy is $18903 \mathrm{KWh} / \mathrm{Year}$. The Grid feed in Power is 9424 $\mathrm{KWh} / \mathrm{Year}$.The Energy from grid is $482 \mathrm{KWh} / \mathrm{Year}$. Annual yield is 1705.26 $\mathrm{KWh} / \mathrm{KWp}$.Return on Assets is $294.81 \%$. Accrued cash flow is calculated for 20 years. The Investment amount, Export tariff for grid feed in, Electricity savings and annual cash flow is calculated for each year. At the end of $20^{\text {th }}$ year Accrued cash is Rs 10,84,048.94 .

Figure 20 and 21 represents economic analysis for 20 years, cash flow table.Figure 22 represents the Electric cost before and after installation of PV.Figure 23 represents overall system yield. Specific $\mathrm{CO}_{2}$ saving through the use of PV energy is $470 \mathrm{~g} / \mathrm{KWh}$. This shows the $\mathrm{CO}_{2}$ emission avoided is $8701 \mathrm{Kg} / \mathrm{Year}$. 


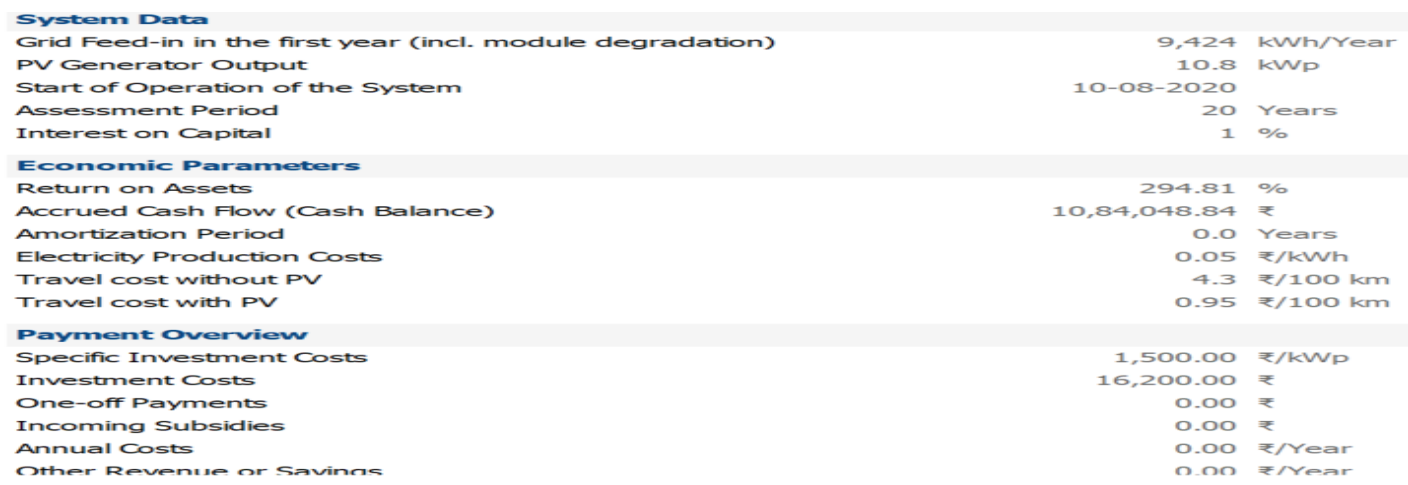

Fig. 20. Economical analysis
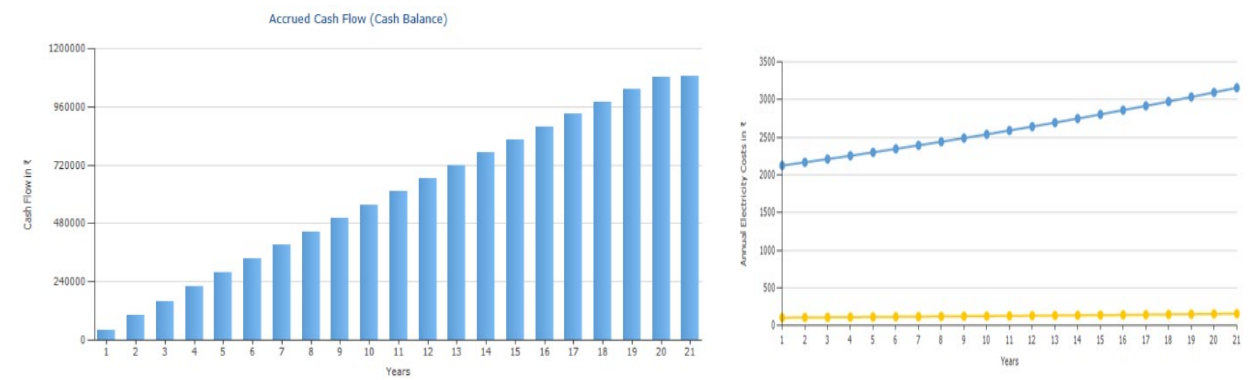

- before installation of PV - Syter installabon of PV

Fig. 21. Cash flow for 20 YearsFig. 22. Electric Cost Trend(Price Increases Rate $2 \%$ )

\begin{tabular}{lc} 
PV Generator Energy (AC grid) & $18,903 \mathrm{kWh}$ \\
\hline Direct Own Use & $809 \mathrm{kWh}$ \\
\hline Battery Charge & $749 \mathrm{kWh}$ \\
\hline Charge of the electric vehicle & $7,921 \mathrm{kWh}$ \\
\hline Grid Feed-in & $9,424 \mathrm{kWh}$ \\
\hline Down-regulation at Feed-in Point & $0 \mathrm{kWh}$ \\
\hline Own Power Consumption & $50.1 \%$ \\
\hline Level of Self-sufficiency & $95.0 \%$ \\
\hline Spec. Annual Yield & $1.750 .26 \mathrm{kWh} / \mathrm{kWp}$ \\
\hline Performance Ratio (PR) & $79.1 \%$ \\
\hline $\mathrm{CO}_{2}$ Emissions avoided & $8,701 \mathrm{~kg} /$ year
\end{tabular}

Fig. 23. Overall System Output

\section{Conclusion}

Using PV sol software three PV module areas are considered with different tracking system like duel axis, single axis and no axis systems. By observing this duel axis tracking system observe 
more irradiance and temperature in a PV module. Hence the energy generated from that particular module is also high. The PV generation is utilized for charging four electrical vehicles, charging the battery system, feeding to grid and supply the electrical appliances for office building and research building. The $50 \%$ of power from PV generation is pumped into grid, $40 \%$ is utilized for charging the electrical vehicle, $5 \%$ is utilized for battery charging and $5 \%$ for electrical appliances. The carbon di oxide emission avoided is $8701 \mathrm{Kg} / \mathrm{Year}$. The financial analysis taken for a period of 20 years and assured cash balance is calculated using PV sol. Hence the Grid connected PV system supplies the Electrical appliances,Electric Vehicles and Battery systems and investigated using PVsol Software with real climatic data in chennai location.

\section{References}

[1] Daw, N.A. and Ghniya, A., Grid connected PV System design and Feasibility Study for the Electrical and Electronics Engineering ,International Journal of Photo EnergyDepartment of University of Tripoli Using PV* SOL Software.

[2] Dondariya, C., Porwal, D., Awasthi, A., Shukla, A.K., Sudhakar, K., SR, M.M. and Bhimte, A., 2018. Performance simulation of grid-connected rooftop solar PV system for small households: A case study of Ujjain, India. Energy Reports, 4, pp.546-553.

[3] Pushpavalli.M and N.M Jothi Swaroopan. " KY Converter with Fuzzy Logic Controller For Hybrid Renewable Pv/Wind Power System." Transactions on Emerging Telecommunications Technologies (2020): e3989, Volume 31, issue 6.

[4] Patarau, T., Petreus, D. and Etz, R., 2015, May. Analysis and optimization of a geothermal, biomass, solar hybrid system: An application of PV* Sol software. In 2015 38th International Spring Seminar on Electronics Technology (ISSE) (pp. 370-375). IEEE.

[5] Pushpavalli, M., and N.M Jothi Swaroopan. "Maximum power tracking for PV array system using fuzzy logic controller." In International conference on intelligent computing and applications, pp. 337-348. Springer, Singapore, 2019.

[6] Sharma, R. and Gidwani, L., 2017, April. Grid connected solar PV system design and calculation by using PV* SOL premium simulation tool for campus hostels of RTU Kota. In 2017 International Conference on Circuit, Power and Computing Technologies (ICCPCT) (pp. 1-5). IEEE.

[7] Murugan, Pushpavalli, and Jothi Swaroopan Nesa Mony. "Implement Using KY Converter for Hybrid Renewable Energy Applications: Design, Analysis, and Implementation." In Advanced Statistical Modeling, Forecasting, and Fault Detection in Renewable Energy Systems. IntechOpen, 2020

[8] Mehrjerdi, H., 2020. Modeling, integration, and optimal selection of the turbine technology in the hybrid wind-photovoltaic renewable energy system design. Energy Conversion and Management, 205, p.112350.

[9] Murtaza, A., Chiaberge, M., De Giuseppe, M. and Boero, D., 2014. A duty cycle optimization based hybrid maximum power point tracking technique for photovoltaic systems. International Journal of Electrical Power \& Energy Systems, 59, pp.141-154.

[10] Illavarason, P., Renjit, J.A. and Kumar, P.M., 2019. Evaluating the Effectiveness of Visual Techniques Methodologies for Cerebral Palsy Children and Analyzing the Global Developmental Delay. In Microelectronics, Electromagnetics and Telecommunications (pp. 99-105). Springer, Singapore. 